\title{
First record of Dentella repens (Rubiaceae) from Madagascar
}

\author{
Sylvain G. Razafimandimbison \& Nadiah Manjato
}

\begin{abstract}
RAZAFIMANDIMBISON, S.G. \& N. MANJATO (2019). First record of Dentella repens (Rubiaceae) from Madagascar. Candollea 74: 43-45. In English, English and French abstracts. DOI: http://dx.doi.org/10.15553/c2019v741a6

A first record of the genus Dentella L. (Rubiaceae) from Madagascar is reported here. Dentella repens (L.) J.R. Forst. \& G. Forst. was collected for the first time in the northwestern part of the island, within Analalava District of the Sofia Region. The material collected possesses all the salient characters of the species (e.g., creeping, prostrate herb, toothed corolla lobes, indehiscent fruits covered by transparent, flattened, bulbous-tipped trichomes). We postulate that the species has most likely recently reached Madagascar via long-distance dispersal either from Sri Lanka, where it is native, or Mauritius, where it has become naturalized.
\end{abstract}

\section{Résumé}

RAZAFIMANDIMBISON, S.G. \& N. MANJATO (2019). Première mention de Dentella repens (Rubiaceae) à Madagascar. Candollea 74: 43-45. En anglais, résumés anglais et français. DOI: http://dx.doi.org/10.15553/c2019v741a6

Le genre Dentella L. (Rubiaceae) est signalé pour la première fois à Madagascar. Dentella repens (L.) J.R. Forst. \& G. Forst. a été récoltée au nord-ouest de l'île, dans le District d'Analalava de la Région Sofia. Le matériel collecté possède tous les caractères essentiels de l'espèce (port herbacé, rampant et prostré, lobes de la corolle dentés, fruits indéhiscents couverts de trichomes transparents et aplatis à extrémité bulbeuse). Nous supposons que l'espèce a récemment atteint Madagascar par dispersion à longue distance, soit à partir du Sri Lanka où elle est indigène, soit de l'île Maurice où elle s'est naturalisée.

\section{Keywords}

RUBLACEAE - Dentella - Madagascar - Biodiversity

Addresses of the authors:

SGR: Swedish Museum of National History, Department of Botany, Box 50007, SE-10405 Stockholm, Sweden. E-Mail: sylvain.razafimandimbison@nrm.se NM: Missouri Botanical Garden, B.P.3319, Antananarivo 101, Madagascar. 


\section{Introduction}

Our knowledge of the Malagasy Rubiaceae has greatly been improved, as a result of extensive field collecting in Madagascar coupled with the phylogenetic and taxonomic studies during the last 20 years or so (e.g., RobBrecht \& MANen, 2006; Razafimandimbison et al., 2008; Bremer \& Eriksson, 2009). In Madagascar, the coffee family (Rubiaceae) is the second largest flowering plant family and the largest woody plant family, with no less than 900 species (DAvis \& Bridson, 2003), including introduced species. Members of this family are important components of various habitats in the country, ranging from evergreen rainforest, sclerophyllous forest, deciduous dry forest and thicket forest, to savanna woodland (Davis \& Bridson, 2003). Almost all species of Rubiaceae are endemic to Madagascar, with the exceptions of a few species, e.g., Guettarda speciosa L. (Guettardeae), Morinda citrifolia L. (Morindeae), Mussaenda arcuata Poir. (Mussaendeae), Oldenlandia capensis L. f., O. herbacea (L.) Roxb., Richardia brasiliensis Gomes (Spermacoceae), that have paleotropical or pantropical distributions. Many herbaceous Rubiaceae (e.g., Oldenlandia spp., Spermacoce spp., all Spermacoceae) commonly occur on roadsides and in grasslands or cultivated areas (DAvis \& Bridson, 2003). However, it is not known whether these are introduced species that have been naturalized.

We report here the first record of the rubiaceous genus Dentella L. from Madagascar (Fig. 1). Dentella is a small genus of eight species of creeping herbs, with six of its species endemic to Australia, one, D. concinna Airy Shaw, to Myanmar and one species, D. repens (L.) J.R. Forst. \& G. Forst., extending from Southeast Asia to subtropical Asia and the southwestern Pacific. The name originated from the Greek word "dentos" (= tooth), referring to its distinct toothed corolla lobes (Fig. 1). The genus is currently classified in the predominantly herbaceous tribe Spermacoceae of the subfamily Rubioideae, and has been shown to be sister to the African genus Pentodon Hochst. (e.g., KÅrened et al., 2007). The Dentella-Pentodon lineage is distinct by its five-merous flowers. Dentella differs from Pentodon by its creeping habit, stipules with short sheaths and numerous narrow fimbriae, lax inflorescences, peltate placentas with a bilobed apex and its dry, indehiscent fruits covered by white, glassy hairs (as opposed to erect herbs, entire stipules, solitary flowers, semi-globose placentas along the septum and glabrous capsules in Pentodon).

Dentella repens occurs throughout tropical Asia to Australasia, from Sri Lanka through India, Bangladesh, Myanmar and Nepal to southern China and south through Indochina, Peninsular Malaysia, the Philippines and Indonesia to Australia, Micronesia and Polynesia (e.g., KÅrehed \& Bremer, 2007). The species is considered to be an introduced weed on Mauritius (Verdcourt, 1983a: 44). Likewise, it has been reported to have been introduced to Mexico and the USA. We report here the first record of $D$. repens from Madagascar. The second author and a co-worker collected a herbaceous plant that has the salient features of this species (Fig. 1). Below, we provide a description of the new collection of $D$. repens based on the fertile material in flower and fruit that was collected in a temporarily inundated area near the Mahavelona Masiloka Swamp in the Antsanifera Fok. of the Antonibe Com., Analalava Dist., Sofia Region (northwestern Madagascar). The swamp was dominated by Nymphaea nouchali Burm. f. (Nymphaeaceae) et Typha domingensis Pers. (Typhaceae).

\section{Description}

Dentella repens (L.) J.R. Forst. \& G. Forst., Char. Gen. P1.: 25, tab: 13.1775 .

$\equiv$ Oldenlandia repens L., Mant. P1. 1: 40.1767.

Lectotypus (designated by VERDCOURT, 1983b): IndiA [?]: sine loco, s.d., Anon. s.n. (LINN no 155/2).

Small prostrate herb, rooting at nodes. Stems and leaves fleshy, leaf blades subsessile, 4-5 × 1.5-2 mm, obovate to spathulate, base narrowed, apex acute; stipules connate. Flowers axillary, solitary, sessile, 5-merous. Calyx tube c. $1 \mathrm{~mm}$ long; lobes 5, subulate. Corolla tube funnel-shaped, greenyellowish, glabrous outside and inside; lobes white, toothed. Stamens 5, included, attached in the middle of corolla tube. Ovary 2-celled; style filiform; stigma 2-lobed. Fruits globose, indehiscent, densely villous with multicellular, transparent, bulbous-tipped trichomes, becoming glabrescent when fully mature, many-seeded with persistent calyx crown. Seeds minute, angular, brown, rugose.

Specimen examined. - Madagascar. Reg. Sofia [Prov. Mahajanga]: Dist. Analalava, Cne. Antonibe, Fkt. Antsanifera, marais de Mahavelona Masiloka, [144ㄴ $47^{\prime \prime S} 47^{\circ} 25^{\prime} 57^{\prime \prime E}$ ], 20 m, 12.IX.2016, fl. \& fr., Manjato \& Avizara 777 (MO, TAN).

Note. - We postulate that $D$. repens may well have reached Madagascar via a long-distance dispersal either from Sri Lanka or Mauritius. On the other hand, it is possible that the species might be present in East Africa and remains unnoticed. In this case, a long-distance dispersal from East Africa to Madagascar cannot be ruled out.

\section{Acknowledgments}

We thank Evah Haririsoa, Avizara Clovis and the VERAMA team, in particular Alain Andrianandraina and Mr Roger Razakamampianina, for their help in the field. 


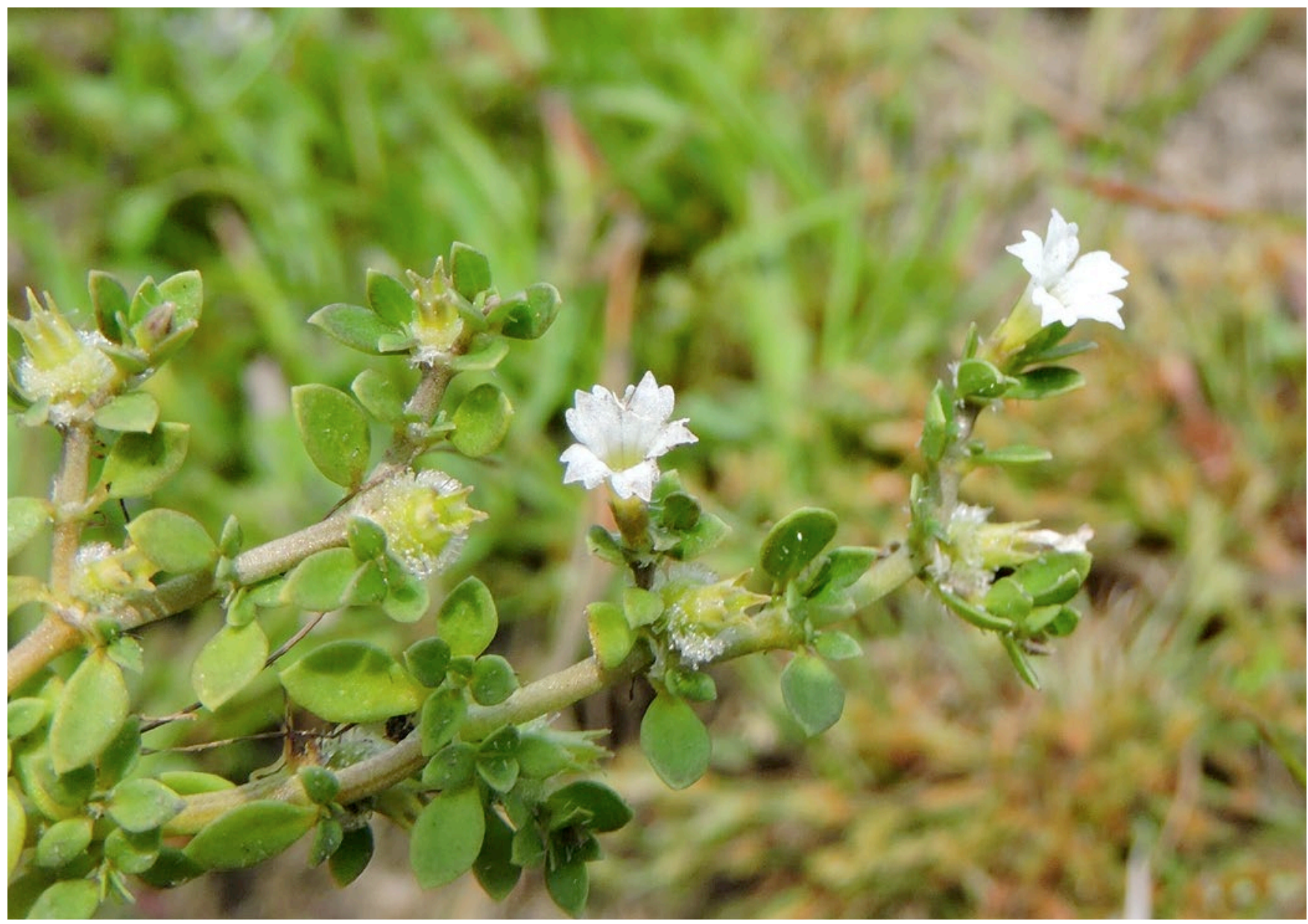

Fig. 1. - Dentella repens (L.) J.R. Forst. \& G. Forst. showing its large corollas with toothed lobes and indehiscent fruits covered by transparent, flattened and bulbous-tipped trichomes.

\section{References}

Bremer, B. \& T. Eriksson (2009). Time tree of Rubiaceae: phylogeny and dating the family, subfamily, and tribes. Int. J. Plant Sci. 170: 766-793.

Davis, A.P. \& D. Bridson (2003). Introduction to the Rubiaceae: Princess Flowers. In: Goodman, S.M. \& J.P. Beamstead (ed.), The Natural History of Madagascar: 431-432. University of Chicago Press.

KÅrehed, J. \& B. Bremer (2007). The systematics of Knoxieae (Rubiaceae) - molecular data and their taxonomic consequences. Taxon 56: 1051-1076.

Razafimandimbison, S.G., C. Rydin \& B. Bremer (2008). Evolution and trends in the Psychotrieae alliance (Rubiaceae) - A rarely reported evolutionary change from many-seeded carpels from one-seeded carpels. Molec. Phylogenet. Evol. 48: 207-159.
Rob brecht, E. \& J.-F. Manen (2006). The major evolutionary lineages of the coffee family (Rubiaceae, Angiosperms). Combined analysis (nDNA abd cpDNA) to infer the possition Coptosapelta and Luculia, and supertree construction based on rbcL, rps16, trnL-trnF, and atpB-rbcL data. A new classification in two subfamilies, Cinchonoideae and Rubioideae. Syst. Geogr. Pl. 76: 85-146.

VErdcourt, B. (1983a). Rubiacées. Fl. Mascareignes 108: 43-44.

Verdcourt, B. (1983b). Notes on Mascarene Rubiaceae. Kerw Bull. 34: $521-574$. 